\title{
Articles
}

http://dx.doi.org/10.15762/ZH.2019.47

ELŻBIETA ALABRUDZIŃSKA

(Nicolaus Copernicus University in Toruń)

\section{The Problem of Identity and the Sense of Loyalty of Jews Coming from the Prussian Partition on the EXample of Alfred Cohn (1901-1961)}

Key words: West Prussia, Greater Poland, German Jews, emancipation, acculturation, assimilation, national identity, to the state, Polish-Jewish relations

The beginning of the $1^{\text {th }}$ century marked a slow but steady growth of the Jewish population in the territories of the Prussian partition. Most Jews lived in Greater Poland. In 1816, almost 52,000 Jewish people lived in the Grand Duchy of Posen, which constituted $6.3 \%$ of the total population and over $40 \%$ of the total number of Jews in Prussia. Until 1849, there had been almost 77,000 Jews in the Province of Posen ${ }^{1}$. On the other hand, in West Prussia, where the Jewish population did not have the right to settle permanently for a long time, in 1816 there were approximately 12,600 Jews, which constituted $2.2 \%$ of the total population. Until 1849 their number increased to almost 23,0002.

Bydgoszcz (Bromberg), which became part of the Grand Duchy of Posen in 1815 , was one of the cities that effectively defended themselves against the influx of Jewish population for a long time. Until 1772, the burghers of Bydgoszcz had prevented the Jews from settling in the town by virtue of royal privileges. It was not until 2 May 1773 that these restrictions were lifted on the basis of the cabinet order of King Frederick II. In 1816, 223 Jews were registered in Bydgoszcz. The intensive development of the Jewish community in the city began in the early 1840s and resulted mainly from the industrialization of

\footnotetext{
${ }^{1}$ Ignacy Schiper, Żydzi pod zaborem pruskim, [in:] Żydzi w Polsce Odrodzonej. Działalność społeczna, gospodarcza, oświatowa i kulturalna, vol. 1, ed. Ignacy SchIPER, Aryeh TARTAKower, Aleksander Hafftka, Warszawa 1932, p. 551; Józef Adelson, Najnowsze dzieje Żydów w Polsce w zarysie (do 1950 roku), ed. Jerzy TomAszewski, Warszawa 1993, pp. 63-64.

${ }^{2}$ Max Aschkewitz, Zur Geschichte der Juden in Westpreussen, Marburg/Lahn 1967, p. 6; Zenon H. Nowak, Sprawa emancypacji Żydów w Prusach Zachodnich w pierwszej połowie XIX wieku, [in:] Emancypacja - asymilacja - antysemityzm. Żydzi na Pomorzu w XIX i XX wie$k u$, ed. Zenon H. NowaK, Toruń 1992, pp. 8-9.
} 
the city. In 1852, 820 Jews lived in Bydgoszcz, whereas by 1871, their number increased to 1,963 . In 1871 , they constituted over $7 \%$ of the city's population, had their representatives in the city council and exerted influence on the economic development of the city ${ }^{3}$.

The development of the Jewish community was also visible in the towns of Bydgoszcz district: Koronowo (Polnisch Krone) and Solec (Schulitz). In the former, 456 Jews lived in $1885^{4}$. It was from Koronowo that Alfred Cohn's ancestors came - both his father Rudolph Cohn and his mother Fanny, nee Cohn as well. They both belonged to the generation born in Koronowo: his father was born in 1867 and his mother in 1875. Alfred's grandfather on his father's side, Eduard Cohn, had a shop with ironware in Koronowo. On the other hand, the father of Alfred's mother, Alexander Cohn, was the owner of a large shop with handicraft products and was a known figure in Koronowo, as he held the office of a deputy burgomaster. In the years 1870-1914 he served as a councillor, and received honorary burghership for his services to the town. Alexander Cohn was awarded the Order of the Crown of the IV grade 5 .

The process of legal emancipation was the second most important phenomenon in the life of the Jewish community of the Prussian partition, apart from its increasing numbers. In the first half of the $19^{\text {th }}$ century, the legal situation of Jews was complicated and varied in particular parts of the Prussian lands, especially in West Prussia. This was due to the fact that individual parts of the province were incorporated into the Prussian state at different times. Jews formally obtained equal civil rights in Prussia under the act of 11 March 1812, which, for obvious reasons, did not include the territories that were then within the borders of the Duchy of Warsaw. After the Congress of Vienna, the territorial scope of the act of 1812 was reduced to the area of Old Prussia ${ }^{6}$.

The efforts of the Jewish population to extend legislation on the Jewish community to the lands of the Prussian partition brought only a partial result in the form of the Temporary Ordinance on Jewry in the Grand Duchy of Posen

${ }^{3}$ Franciszek Mincer, Dzieje Bydgoszczy do roku 1806, Zielona Góra 1992, pp. 343 ff.; Kazimierz WaJDA, Ludność, jej rozwój i struktura, [in:] Historia Bydgoszczy, vol. 1: Do roku 1920, ed. Marian Biskup, Warszawa-Poznań 1991, pp. 469-470; idem, Przemiany terytorialne i ludnościowe w latach 1850-1914, [in:] ibid., p. 513; Zdzisław BIEGAŃski, Mniejszość żydowska w Bydgoszczy 1920-1939, Bydgoszcz 1999, pp. 19 ff.

${ }^{4}$ Bohdan Wasiutyóski, Ludność zydowska w Polsce w wiekach XIX i XX. Studium statystyczne, Warszawa 1930, p. 163.

${ }^{5}$ Alfred Cohn, Erinnerungen an Bromberg. Wspomnienia o Bydgoszczy, ed. Elżbieta AlaBRUdZIŃsKA, Barbara JANISZEWSKA-MinCER, Toruń 2001, pp. 192-194.

${ }^{6}$ M. Aschkewitz, op.cit., pp. 51 ff.; Piotr WróBeL, Żydzi wielkopolscy przed I wojna światowa, Biuletyn Żydowskiego Instytutu Historycznego w Polsce, 1991, no. 1, p. 35; Zenon H. Nowak, Dzieje Żydów na Pomorzu. Stan badań i postulaty badawcze, [in:] Mniejszości narodowe i wyznaniowe na Pomorzu w XIX i XX wieku, ed. Mieczysław Wojciechowski, Toruń 1998, p. 29. 
issued by Eduard Flotwell, the governor of the Province of Posen, on 1 June 1833. According to the new regulations, Jews were divided into two groups: 'naturalized' and 'tolerated'. The basis for the division was mainly a property qualification, education and service for the country. Moreover, only people who spoke German in public life were naturalized. Only 'naturalised' Jews were granted the right to freely choose their place of residence and profession, purchase real estate, and enjoy full civil rights. E. Flotwell's ordinance was to speed up the assimilation of the Jewish population and largely contributed to achieving this goal $^{7}$.

In the following decades, the Prussian legislation lifted most of the restrictions on the rights of the Jewish population, as well as the differences in this respect that existed in individual countries and provinces. In 1845, Jews were included in the conscription for compulsory military service with the simultaneous cancellation of recruitment tax. Two years later, under the Jewish Population Act, which regulated many previously undefined issues, the 'tolerated' Jews received the same rights as the 'naturalized' ones. The Prussian Constitution of 1850 confirmed the legal equality of the Jewish population, and full equality of rights with the rest of the citizens was brought by the law of the North German Confederation of 3 July 1869. Formally, the constitution of 1871 put an end to the process of legal emancipation of the Jews in the German Reich, as well as to the existing differences in the legal situation in individual German states. The Jewish community was then guaranteed legal equality in economic, social and political aspects of life ${ }^{8}$.

Fanny and Rudolph Cohn moved from Koronowo to Bydgoszcz and decided to get married at the beginning of April 1900. Moreover, they bought a house in Bydgoszcz at Friedrichstraße 15 (now Dtuga St.), at the corner of Hofstraße (now Jana Kazimierza St.), where they set up a large shop offering ironware, home appliances and kitchen equipment, and their private apartment on the first floor. The business flourished, which was evidenced by the fact that in 1908, when the "Chaskel" dormitory for students located on the second floor of the house was closed down, the whole floor was used as a warehouse for the Cohns' shop. The house on the corner of Friedrichstraße and Hofstraße was connected with the family's private and professional life for

${ }^{7}$ Artur Eisenbach, Emancypacja Żydów na ziemiach polskich 1785-1870 na tle europejskim, Warszawa 1988, pp. 310-312; I. Schiper, op.cit., pp. 555-556; Sophia Kemlein, Die Posener Juden 1815-1848. Entwicklungsprozesse einer polnischen Judenheit unter preußischer Herrschaft, Hamburg 1997, pp. $96 \mathrm{ff}$.

${ }^{8}$ A. Eisenbach, op.cit., pp. $314 \mathrm{ff}$.; Magdalena Niedzielska, Życie polityczne i kulturalne Torunia (1815-1914), [in:] Historia Torunia, vol. 3, part 1: W czasach zaboru pruskiego (1793-1920), ed. Marian Biskup, Toruń 2003, pp. 292-293; P. WróBEL, op.cit., p. 38. 
20 years. Three Cohn children were born here: the oldest Alfred in 1901, Edith in 1902 and the youngest Heinz in $1906^{9}$.

Alfred Cohn's memoirs published in $2001^{10}$ cover the years $1900-1920$, i.e. the whole period of his family's residence in Bydgoszcz. They are a valuable source of knowledge about the life of the author himself and his loved ones, but they also show us a vivid picture of the whole Jewish population in this city. The memoirs were written down in their original version in the interwar period. Alfred Cohn presented them to his father in 1934. During the fighting for Wrocław (Breslau) in 1945, they were destroyed, along with the documents and photographs attached to them. Alfred immediately decided to make a reconstruction of the original diary, but he made some cuts in it, so it is not known to what extent it is faithful to the original version ${ }^{11}$.

The family that emerges from the pages of A. Cohn's diary can be described as 'German Jews'. The Cohn family spoke German at home, celebrated German public holidays and was closely related to Germany in terms of nationality. It was not out of the ordinary as most of the Jews of the Prussian partition were subjected to acculturation or assimilation in the second half of the $19^{\text {th }}$ century, which incorporated them in the German community ${ }^{12}$. The assimilation processes were largely due to legal emancipation of the Jewish population. It should be remembered, however, that these two phenomena overlapped in connection with the economic advancement of Jews and their obtaining of civil rights. Strong assimilation tendencies were already visible in the generation born in the second half of the $19^{\text {th }}$ century, that is the generation of A. Cohn's parents. However, assimilation reached its greatest intensity at the turn of the $20^{\text {th }}$ century. The Jewish population increasingly integrated with the German society. This integration consisted mainly in the adoption of German culture and customs, and a departure from traditional names and clothing. Jews often sent their children to Jewish schools with German as the language of instruction. It was common for the Jewish community to emphasise German patriotism and identify with the German state ${ }^{13}$.

${ }^{9}$ A. CoHn, op.cit., pp. $23 \mathrm{ff}$.

${ }^{10}$ Ibid.

${ }^{11}$ Ibid., pp. $13 \mathrm{ff}$.

${ }^{12}$ For more on the concepts of acculturation and assimilation, see S. KemLeIN, op.cit., pp. 237 ff.; Jacob TourY, Soziale und politische Geschichte der Juden in Deutschland 1847-1871. Zwischen Revolution, Reaktion und Emanzipation, Düsseldorf 1977, pp. 138 ff.; Z. H. NowAK, Sprawa emancypacji, pp. $7 \mathrm{ff}$.; Theodore R. Weeks, Jews on the Polish Lands and Polish-Jewish Relations 1795-1914, [in:] Historie Polski w XIX wieku, vol. 4: Narody, wyznania, emigracje, porównania, ed. Andrzej NowaK, Warszawa 2015, pp. 90-91.

${ }^{13}$ I. Schiper, op.cit., p. 553; Mieczysław Wojciechowski, Niemcy, Polacy i Żydzi w Prusach Zachodnich w latach 1877-1920, [in:] Ze soba, obok siebie, przeciwko sobie. Polacy, Żydzi, Austriacy i Niemcy w XIX i na początku XX wieku, Kraków 1995, p. 171; J. Adelson, op.cit., 
All these tendencies were also visible in the Jewish community in Bydgoszcz. Jewish children learned Hebrew here only once or twice a week in the Jewish school that operated at the synagogue. The religious rites in the synagogue were held in German. The assimilation process was advanced, which is evidenced by the fact that A. Cohn, when writing about the Jews of Bydgoszcz, usually uses the term 'fellow believers' ${ }^{14}$. The Jews were increasingly becoming a religious community, not a national one. It is difficult to determine when they actually started to consider themselves as Germans of Jewish faith, because this cannot be proved only by the fact that they used German, or even claimed it was their mother tongue, as the literature on the subject has usually assumed so far. The thesis of Olgierd $\mathrm{Kiec}^{15}$ seems to be the most convincing. It was formulated during the research on Protestant missions among the Jews of Greater Poland, and it was based on the observations of pastors of that time, who claimed that at least until the 1880s Jews considered themselves as representatives of a separate nation, and therefore they were also perceived as such by both Germans and Poles. However, this state of affairs changed in the following decades and at the beginning of the $20^{\text {th }}$ century, i.e. in the times of A. Cohn's childhood, the fact that the Jewish population perceived themselves as a religious group was increasingly common.

The concept of assimilation, which considers 'Jewry' solely as a religious denomination and not as a national community, obviously aroused opposition from Orthodox Jews. One of those who represented them was Hirsch Zwi Kalischer from Torun (Thorn), who was among the leading pioneers of the Zionist movement in the second half of the $19^{\text {th }}$ century. He opposed the concept of assimilation to national-Jewish ideas, closely related to religion. In his work entitled Drischat Sion he showed the concept of Palestine colonization and the creation of a Jewish national state ${ }^{16}$.

It was the assimilation, next to migration, that caused the growth and then systematic decrease in the number of Jews in the Prussian partition at the turn of the $20^{\text {th }}$ century. In Germany, the Jews who claimed German was their mother tongue in the censuses, were counted as Germans. This is how in

p. 69; Tomasz ŁAszKiEwicz, Żydzi w Inowrocławiu w okresie międzywojennym (1919-1939), Inowrocław 1997, p. 11; Olgierd KIEC, Protestantyzm w Poznańskiem 1815-1918, Warszawa 2001, p. 359.

14 “Glaubensgenossen”; A. CoHn, op.cit., pp. 46 ff. Cf. Piotr WróBEL, Zarys dziejów Żydów na ziemiach polskich $w$ latach 1880-1918, Warszawa 1991, pp. $36 \mathrm{ff}$.

${ }^{15}$ O. KIEC, op.cit., p. 359.

${ }^{16}$ Zenon H. Nowak, Dzieje gminy żydowskiej w Toruniu (1815-1939). Zarys, [in:] Mniejszości narodowe $i$ wyznaniowe $w$ Toruniu $w$ XIX $i$ XX w., ed. Mieczysław Wojciechowski, Toruń 1993, pp. 32-33; M. NiedZIELSKA, op.cit., p. 301. 
some towns in the Province of Posen and West Prussia the Jewish population blended into German community, e.g. in Chełmża (Kulmsee), in the census of 1910, out of 239 people of the Jewish faith 238 claimed German as their mother tongue. More and more statistical summaries were commented with the statement: "keine Juden mehr"17. In the aftermath of migration, conversions and mixed marriages the number of people of Jewish faith was also decreasing. By 1880, in the Province of Posen it had fallen to 56,609 people $(3.3 \%$ of the total population), in 1900 it was only 35,327 people (1.9\%), and in 1910 - 26,512 people (1.3\%). In West Prussia in 1885 there were 24,654 people of Jewish faith (1.7\% of the total population), while in $1910-13,954$ (0.8\%). In 1910, there were 1,349 Jews living in Bydgoszcz, which constituted 2.3\% of its total population ${ }^{18}$.

The fact that German was spoken in the synagogue in Bydgoszcz had, apart from its national significance, a strong religious dimension. It was due, as in the whole Prussian partition, to the attempts to reform the Synagogue related to the replication of the Evangelical Church model. Apart from the German language, other borrowings included simplifications in the liturgy and playing the organ, which was purchased in the synagogue of Bydgoszcz in 1898. This caused the services at the synagogue to resemble the Protestant liturgy to some extent ${ }^{19}$. The changes were also related to the secularization of life in Jewish communities and less rigorous discharging of religious duties. They were also visible in the Cohn family and were expressed in an apparent contradiction between the claims of the author of the memoirs about the descent of both his parents from very religious families, and descriptions of the Shabbat and religious holidays during his childhood. The Cohns' shop was open on Saturdays and most Jewish holidays, like almost all Jewish shops in Bydgoszcz. The only exceptions were the Jewish New Year (Rosh Hashanah) and the Day of Atonement (Yom Kippur). The importance of these two holidays was also visible in the Bydgoszcz synagogue, which was frequented in very large numbers only on those occasions. In the Cohns' house, it was the mother who tried

${ }^{17}$ Kazimierz WajDA, Awans i asymilacja. Na przykładzie społeczności żydowskiej Chetm$\dot{z} y$ w XIX i na poczatku XX wieku, [in:] Emancypacja - asymilacja - antysemityzm. Żydzi na Pomorzu w XIX i XX wieku, ed. Zenon H. Nowak, Toruń 1992, p. 24; Dariusz Matelski, Niemcy w Polsce w XX wieku, Warszawa-Poznań 1999, p. 122; J. Adelson, op.cit., pp. 77-78.

${ }^{18}$ B. Wasiutyński, op.cit., pp. 11 ff.; M. Aschkewitz, op.cit., pp. 130 ff.; K. Wajda, Przemiany terytorialne, p. 513.

${ }^{19}$ Z. H. NowaK, Dzieje Żydów, p. 29; idem, Sprawa emancypacji, pp. 13 ff.; Elżbieta AlaBRUDZIŃsKa, Stosunki religijne $w$ Toruniu (1815-1914), [in:] Historia Torunia, vol. 3, part 1: W czasach zaboru pruskiego (1793-1920), ed. Marian BIskup, Toruń 2003, pp. 416-417; Z. BiEGAŃski, op.cit., p. 23. Cf. François Guesnet, Polnische Juden im 19. Jahrhundert. Lebensbedingungen, Rechtsnormen und Organisation im Wandel, Köln-Weimar-Wien 1998, pp. $286 \mathrm{ff}$. 
to cultivate Jewish religious traditions, forbidding her children, for example, writing on Shabbat ${ }^{20}$.

Education of Jewish children and youth in public schools had a significant influence on the acceleration of secularization and assimilation processes. Alfred Cohn attended the Royal Gymnasium at Weltzienplatz (present day Plac Wolności) in Bydgoszcz. Education at a German school gave him the opportunity, like to other Jewish children, of constant contact with non-Jewish environment. Throughout the whole period of their high school education, young people were influenced by the values of German culture "to an extent that even lesson of Jewish religion resembled in their form the teaching of Christian religion"21.

Lucjan Broniewicz conducted interesting research on Jewish high school graduates in West Prussia ${ }^{22}$. In its light, the education of A. Cohn is a very typical example illustrating the trends occurring among the Jewish population of that period. The researcher found that people of Jewish origin chose Evangelical gymnasiums the most often. They were mostly members of affluent merchant families. The importance that this social group attached to the education of their children is evidenced by the fact that the percentage of Jewish high school graduates in some high schools was several times higher than the percentage of Jews in the community of West Prussia ${ }^{23}$. Only a small part of Jewish high school graduates did not continue to acquire higher education. The most frequently chosen fields of study were medicine and law. This was due, on the one hand, to the still persisting informal obstacles that hindered Jews in their careers in some professions, and on the other hand, to the tradition of being independent contractors and choosing professions that allowed financial stability ${ }^{24}$.

${ }^{20}$ A. CoHn, op.cit., pp. $55 \mathrm{ff}$.

${ }^{21}$ Z. H. NowAK, Dzieje Żydów, p. 31. See A. CoHn, op.cit., pp. 67 ff.; Hans-Werner RAUTenberg, Zur Geschichte des Judentums in Pommern und Westpreußen zwischen Emanzipation und Erstem Weltkrieg, [in:] Juden in Ostmitteleuropa. Von der Emanzipation bis zum Ersten Weltkrieg, hrsg. v. Gotthold Rhode, Marburg/Lahn 1989, p. 65; Stefi JersCH-Wenzel, Zur Geschichte der jüdischen Bevölkerung in der Provinz Posen im 19. Jahrhundert, [in:] ibid., pp. 80 ff.; Jörg H. FeHrs, „..., daß sie sich mit Stolz Juden nennen“. Die Erziehung jüdischer Kinder in Ost- und Westpreußen im 19. Jahrhundert, [in:] Zur Geschichte und Kultur der Juden in Ost- und Westpreußen, hrsg. v. Michael Brocke, Margret Heitmann, Harald Lordick, Hildesheim-Zürich-New York 2000, pp. 267-269.

${ }^{22}$ Lucjan Broniewicz, Tworzenie się inteligencji żydowskiej w Prusach Zachodnich. Żydowscy absolwenci gimnazjów przed 1914 rokiem, [in:] Emancypacja - asymilacja - antysemityzm. Żydzi na Pomorzu w XIX i XX wieku, ed. Zenon H. Nowak, Toruń 1992, pp. 27 ff.

${ }^{23}$ A similar trend continued throughout the Reich. As early as in 1860 Jews constituted 6\% of all high school students, while their participation in the society of the Reich amounted to approximately 1\%. See P. WRóBeL, Żydzi wielkopolscy, p. 41.

${ }^{24}$ L. Broniewicz, op.cit., pp. $34 \mathrm{ff}$. 
It should be stressed that high school graduates of Jewish origin were most often characterized by deep adherence to the values characteristic of German culture. In this way, the young Jewish intelligentsia became a carrier of farreaching assimilation trends. The progress of these trends reflects the fact that German became the mother tongue of the Jews, and the almost entire population of Jewish faith claimed this language as their mother tongue in the aforementioned census of $1910^{25}$.

The process of the Jews' integration into German society usually did not end with cultural and linguistic integration but led to their identification with the German state. The Jewish population was increasingly characterized by German patriotism and loyalty to German authorities. For example: the Jews of the Poznan administrative region became involved in the Prussian state during the Greater Poland uprising in 1848. They supported, inter alia, the German national committees in Poznań and Bydgoszcz, and took part in battles against Polish insurgents in several cities, serving in the ranks of German militia. The insurgents reacted by hostile speeches addressed against the Jews. Starting from 1848, Polish-Jewish relations systematically deteriorated, which was particularly evident in the Province of Posen ${ }^{26}$. The hostility of the Poles was caused primarily by the creation of an anti-Polish front jointly by the Jews and the Germans in response to nationality conflicts and loyalty towards the Prussian state demonstrated by the Jews. The Polish-Jewish antagonisms in the Province of Posen intensified in the period of Germanization policy introduced by Chancellor Otto von Bismarck, which met with support from the Jewish population. The Poles' reluctance was also aroused by the enthusiastic attitude of the majority of Jews during the Franco-Prussian War in the years 1870-1871, and towards the created German Empire ${ }^{27}$.

This type of antagonism did not appear in Polish-Jewish relations in West Prussia. Especially in the south-eastern part of the administrative region of Kwidzyn (Marienwerder), i.e. in the districts of Brodnica (Strasburg), Chełmno (Kulm), Grudziądz (Graudenz), Sztum (Stuhm), Toruń and Lubawa (Löbau), Jews happened to establish contacts and cooperation with Poles, also from Congress Poland. It should be noted that Jews from the region of the

${ }^{25}$ Ibid., p. 40; Z. H. Nowak, Dzieje Żydów, p. 31. Cf. Peter Schumann, Über jüdische Deutsche und die Assimilation, [in:] Emancypacja - asymilacja - antysemityzm. Żydzi na Pomorzu w XIX i XX wieku, ed. Zenon H. NowaK, Toruń 1992, pp. $165 \mathrm{ff}$.

${ }^{26}$ S. Kemlein, op.cit., pp. $96 \mathrm{ff}$.

${ }^{27}$ Mirosław Cygański, Żydzi poznańscy, pomorscy oraz śląscy wobec Polaków i Niemców pruskich w latach 1816-1939, Studia Śląskie, vol. 55: 1997, pp. 61 ff.; P. WRóBEL, Żydzi wielkopolscy, pp. 39-41; Wolfgang Wippermann, Probleme und Aufgaben der Beziehungsgeschichte zwischen Deutschen, Polen und Juden, [in:] Deutsche - Polen - Juden. Ihre Beziehungen von den Anfängen bis ins 20. Jahrhundert, hrsg. v. Stefi Jersch-Wenzel, Berlin 1987, pp. 17-20; T. R. WeEKs, op.cit., pp. 77-78. 
lower Vistula River helped the insurgents of the January Uprising in the years $1863-1864^{28}$.

The difference in the intensity of the Polish-Jewish dispute in the area of Poznań and West Prussia had its origins in the size and economic position of the Jewish population, but also in their political activity in public life. In the Province of Posen, the local Jewish elites were very active in the local government, which was evident in the over-representative participation of Jews in the urban authorities, e.g. in Bydgoszcz. In the years 1879-1892 over 200 Jewish politicians were elected as city councillors and deputies in the Province of Posen. At the beginning of the $20^{\text {th }}$ century the composition of the city council of Poznań was as follows: 33 Germans of Christian denominations, 16 Germans of Jewish faith and 7 Poles $^{29}$.

In A. Cohn's memoirs there are no signs of mutual hostilities between Jews and Poles. First of all, Alfred's school and subsequent studies provided him with the opportunity to contact Polish children and youth. He knew at least basic Polish and read the Polish press. As a child, he liked to watch the activities of the editorial office of Dziennik Bydgoski, located at Hofstraße, from the windows of his house. The desire to get to know this newspaper was the most important reason for him to start learning Polish ${ }^{30}$.

The image of the Jewish community of Bydgoszcz outlined in the memoirs may come as a great surprise. Despite a certain openness to Polishness on the one hand, and almost complete German identity on the other, the memoirs depict a largely closed social group. Only Jews were friends of the Cohns' house. The Friedrichstraße district was in fact a 'Jewish quarter', with Jewish shops and cafes. The Jews of Bydgoszcz supported each other, the Cohns went shopping exclusively to Jewish shops, were treated by Jewish doctors and dentists, and made use of the services of Jewish craftsmen. They remained within the circle of the Jewish community and lived its life at all times ${ }^{31}$. This creates a picture that contradicts the intense desire of the Jewish population to blend in with German society. To some extent, this contradiction is explained by the results of research on Jews in the German Empire: "[...] at the end of the $19^{\text {th }}$ century, the majority of the Jews in Germany certainly did not belong to the old Jewish world; however, nor were they, as they often wanted to believe, completely melted into their new surroundings. Most of them lived in the third sphere [...]. They functioned in their own German-Jewish cultural system, creating an overall structure of public and private associations and a network

\footnotetext{
${ }^{28}$ Z. H. NowaK, Sprawa emancypacji, p. 15; M. CYgaŃski, op.cit., p. 67.

${ }^{29}$ M. CYgaŃsKi, op.cit., p. 65; Z. BIEGAŃski, op.cit., p. 25.

${ }^{30}$ A. CoHn, op.cit., pp. $28 \mathrm{ff}$.

${ }^{31}$ Ibid., pp. $46 \mathrm{ff}$.
} 
of educational institutions. [...] Representing diverse, often conflicting ideological positions, they strove to build a common Jewish tradition" ${ }^{\text {"32 }}$.

For the Cohns, the participation in the cultural life of Bydgoszcz was an opportunity to go beyond this closed community. Alfred's parents sometimes took part in the events organised by the Masonic lodge and in lectures organised by the German Society of Art and Science in Bydgoszcz (Deutsche Gesellschaft für Kunst und Wissenschaft). The young Cohns, on the other hand, preferred the theatre and participated in almost all performances staged both at the theatre at Theater-Platz (present day Plac Teatralny) and on other stages of Bydgoszcz. On one of them, the Patzer's stage, plays were also performed in Polish, but the Cohns remained loyal to German-language works ${ }^{33}$.

The First World War turned out to be a breakthrough period for the Jews from the Prussian partition, just like for the Jewish population of the whole Central Europe. The specificity of their situation is best reflected in the words of Piotr Wróbel: "The outbreak of the First World War surprised Central European Jews and put them in a difficult situation. They did not consider any of the fighting nations as an enemy. They had no borders that they would have to defend. They were not interested in an armed conflict and could not see the point of it, yet they had to participate in it and they belonged to one of the nations that was persecuted by it the most" ${ }^{34}$. Nevertheless, despite this element of surprise, the majority of Jews in the Prussian partition shared the national enthusiasm of the Germans in August 1914. The Jewish youth volunteered to join the army or reported for service in the structures of the Red Cross. Jewish communities organised care for wounded soldiers and prisoners of war. Jews considered it their natural duty towards the German homeland ${ }^{35}$.

Hence the great disillusionment and anxiety of the Jews about the fall of the German Empire. Most of the Jewish community of the Province of Posen was hostile towards the Greater Poland uprising. This was also the position of the two main Jewish organizations in Greater Poland: the Jewish People's Council (despite the initially pro-Polish declarations) and the Central Association of German Citizens of Jewish Faith of Greater Poland. The Jews condemned the armed combat as a way of resolving the issue of where Greater Poland belonged and postulated they would wait for the decision of the Paris Peace Conference. Also a large part of the Jewish population in West Prussia took a stand against the separation of these lands from Germany. In May 1919, the Jewish community in Gdańsk (Danzig) issued a protest in this matter,

${ }^{32}$ Shulamit Volkov, Pomysł na nowoczesność. Żydzi niemieccy w XIX i na początku XX wieku, trans. Justyna Górny, Patrycja Pieńkowska, Warszawa 2006, p. 136.

${ }^{33}$ A. CoHn, op.cit., pp. $107 \mathrm{ff}$.

${ }^{34}$ J. AdELSON, op.cit., p. 104.

${ }^{35}$ Ibid., p. 106; M. WojCIECHOWski, op.cit., pp. 182-183. 
emphasizing that its members are and want to remain Germans and do not agree to the separation of this German area from their homeland ${ }^{36}$.

Unfortunately, A. Cohn's diary contains, little information about the period of the First World War, the revolutionary coup in Bydgoszcz in November 1918 and the period of the Greater Poland uprising. Many of his relatives fought at the front, some were wounded, but none of them died. Also some of Alfred's schoolmates were conscripted into the army. It was not until the end of the war at the age of 17 that he himself had to appear before a military draft commission for the first time, so he avoided taking part in the warfare. At that time, he was busy preparing for his final school exams and choosing further education. In 1919, having graduated from high school, he started medical studies in Ber$\operatorname{lin}^{37}$. From then on, he came to Bydgoszcz only during his holidays.

Germany's defeat in the First World War and the provisions of the Treaty of Versailles which determined the incorporation of Bydgoszcz into the Polish state put the Cohn family before one of the most important decisions in their lives. The memoirs make it possible to partially recreate the motives for making this decision. It seems that the issue that determined the choice of the Cohns was the difficulty in communicating with people already migrating to Bydgoszcz from former Congress Poland at that time. First of all, Alfred pointed out the language problems, emphasizing good relationship with German-speaking representatives of the Polish community in Bydgoszcz so far. However, no reservations of a national nature ever became an issue - A. Cohn did not see any differences between German Jews and 'Aryan Germans ${ }^{38}$. In this way, the Cohn family found themselves among those who opted for Germany. In October 1920, the family members decided to move to Berlin, where Alfred's maternal grandmother lived since 1918. On 15 December 1920 the Cohns moved to the capital of Germany.

The same decision was made by a vast majority of Jews in Bydgoszcz. Nearly 1,000 people opted for Germany and left the city together with the German population in 1918-1921. The situation was similar in the former Prussian partition. After part of the lands of the Prussian district came under Polish rule, the Jews mostly retained their sense of loyalty towards the German state, which they regarded as their homeland. Their attitude towards Poland, after Greater Poland and Pomerania came under its jurisdiction, did not differ from that of the German population. Conversely, Polish authorities and the

${ }^{36}$ M. Wojciechowski, op.cit., p. 185; M. CYgański, op.cit., pp. 73-74.

${ }^{37}$ A. Conn, op.cit., pp. $164 \mathrm{ff}$. On the attitudes of German and Polish population of Bydgoszcz in the years 1914-1918, see Mieczysław Wojciechowski, W okresie pierwszej wojny światowej i powstania wielkopolskiego (1914-1920), [in:] Historia Bydgoszczy, vol. 1: Do roku 1920, ed. Marian Biskup, Warszawa-Poznań 1991, pp. $608 \mathrm{ff}$.

${ }^{38}$ A. CoHN, op.cit., pp. 185-186. 
population also treated Jews as representatives of German society ${ }^{39}$. According to the census of 1921 there were 10,397 Jews living in the region of Poznan and 2,927 in the areas of West Prussia incorporated to Poland ${ }^{40}$. This meant that from both these regions almost the same percentage of the total Jewish population living there emigrated to Germany - 61\% from the region of Poznań, and $62 \%$ from Pomerania. Emigration on a smaller scale continued in the following years.

For the Jewish people who decided to stay in Bydgoszcz, the year 1920 also marked the beginning of a completely new era. Not only did they live in a completely different environment from that time on, but they were also faced with a growing migration of Jews from eastern and central Poland. The great difficulties in the coexistence of the 'local' Jews with the migrating Jews showed what great differences divided them. It would be no exaggeration saying that they differed in everything: religiousness, mentality, way of life, political views, and even their mother tongue, because the 'locals' did not know Yiddish. Throughout the interwar period there was a deep separation between the two groups, and the conflicts that existed in the Jewish community on this basis fully revealed how unique the German Jews were. In the 1930s, the migrating group already dominated in Bydgoszcz over the 'local' community, and the conflicts became so acute that the Polish authorities decided to introduce compulsory administration. The same took place in other Jewish communities of the former Prussian partition ${ }^{41}$.

After the Cohn family moved from Bydgoszcz to Berlin, Alfred continued his medical studies in Heidelberg. After he graduated and married Lotte Cohn, he moved to Wrocław and worked as a doctor. Here, in 1929, their only child

${ }^{39}$ Elżbieta AlabrudzińsKa, Mniejszości wyznaniowe w Bydgoszczy w latach 1920-1939, Toruń 1995, pp. 16 ff.; Z. H. Nowak, Dzieje Żydów, pp. 33-34; Janusz KutTA, Społeczeństwo Bydgoszczy w latach 1920-1939, [in:] Historia Bydgoszczy, vol. 2, part 1, ed. Marian BIskup, Bydgoszcz 1999, pp. 178 ff.; D. Matelski, op.cit., p. 122.

${ }^{40}$ Jan SzIling, Gminy wyznaniowe żydowskie $w$ województwie pomorskim $w$ latach 1920-1939 (Liczebność i rozmieszczenie), [in:] Mniejszości narodowe i wyznaniowe w województwie pomorskim w okresie międzywojennym (1920-1939), ed. Mieczysław WoJCIECHOwsKi, Toruń 1991, pp. 49 ff.; M. WojCIECHOWski, Ze sobq, obok siebie, p. 187; M. CYGAŃski, op.cit., p. 75.

${ }^{41}$ E. Alabrudzińska, Mniejszości wyznaniowe, pp. 66 ff.; Z. H. Nowak, Dzieje Żydów, p. 34; Jerzy Tomaszewski, Zarys dziejów Żydów w Polsce w latach 1918-1939, Warszawa 1990, pp. 18 ff.; Zofia WAszkiewicz, Żydzi w Grudziądzu (1920-1939), [in:] Emancypacja - asymilacja - antysemityzm. Żydzi na Pomorzu w XIX i XX wieku, ed. Zenon H. Nowak, Toruń 1992, pp. 102 ff.; Mieczysław Wojciechowski, Mniejszości narodowe w Toruniu w okresie międzywojennym (1920-1939), [in:] Historia Torunia, vol. 3, part 2: W czasach Polski Odrodzonej i okupacji niemieckiej (1920-1945), ed. Marian BIskup, Toruń 2006, pp. 211 ff.; Zenon H. NowAK, Gmina Wyznaniowa Żydowska w Toruniu w latach 1920-1939, [in:] Gminy Wyznaniowe Żydowskie $w$ województwie pomorskim $w$ okresie międzywojennym (1920-1939), ed. Jan SzILING, Toruń 1995, pp. $61 \mathrm{ff}$. 
was born - daughter Ilse. We know about this period of A. Cohn's life only from the calendar attached to his memories. On the other hand, Willy Cohn is yet another author of very valuable, extensive memoirs and diaries depicting the life of the Jewish community of the interwar period and the Second World War (until 1941) in Wrocław ${ }^{42}$. However, they do not contain any mention of A. Cohn and his family, and there was no kinship between both authors of the memoirs ${ }^{43}$.

Alfred Cohn, his wife and daughter managed to survive the Second World War. Alfred was in concentration camps twice - most probably in Buchenwald in 1938 and in Groß Rosen between 1944 and 1945. His parents were deported from Berlin to Theresienstadt in 1942 where they died. His brother Heinz and his wife only just managed to go to Palestine. Most of the Cohn family died in Theresienstadt or in German death camps in occupied Poland ${ }^{44}$.

When the Second World War ended, A. Cohn and his closest family were living in Wrocław. They decided to stay in Poland. Alfred worked in Wrocław as a doctor until his death in 1961 . He died together with his wife as a victim of a robbery ${ }^{45}$.

We do not know the circumstances in which A. Cohn decided to stay in Poland in 1945. It is also difficult to use scientific literature in this case, because the question of the return of German Jews to Poland after the Second World War or, as in the case of A. Cohn's staying in the territories assigned to the Polish state, has not been studied in detail so far. When researching the fate of Jews saved after the Second World War, historians focus on the area of interwar Poland, while German Jews who survived in the so-called Recovered Territories remain outside the main circle of research interest ${ }^{46}$. It is therefore worth quoting the findings of Janusz Mieczkowski ${ }^{47}$ and Mirosław Golon ${ }^{48}$ concerning Western Pomerania. When analysing the situation of Szczecin (Stettin)

${ }^{42}$ Willy CoHn, Verwehte Spuren. Erinnerungen an das Breslauer Judentum vor seinem Untergang, hrsg. v. Norbert ConRADs, Köln-Weimar-Wien 1995; idem, Żadnego prawa - nigdzie. Dziennik z Breslau 1933-1941. Wybrane fragmenty, ed. Norbert ConRaDs, trans. Viktor GroTOwicz, Wrocław 2010.

${ }^{43}$ Although there is a mention of Alfred Cohn in the diary, it is a different person and the similarity of names is coincidental. See W. CoHn, Żadnego prawa, pp. 120-121.

${ }^{44}$ A. Cohn, op.cit., pp. 192-196; Leszek ZiąTкоwsкi, Dzieje Żydów we Wrocławiu, Wrocław 2000, pp. 108-109.

${ }^{45}$ A. CoHn, op.cit., pp. 6-7.

${ }^{46}$ August Grabski, Maciej Pisarski, Albert Stankowski, Studia z dziejów i kultury Żydów w Polsce po 1945 roku, Warszawa 1997, pp. $14 \mathrm{ff}$.; J. Adelson, op.cit., pp. $387 \mathrm{ff}$.

${ }^{47}$ Janusz Mieczkowski, Żydzi, Niemcy i Ukraincy na Pomorzu Zachodnim w latach 1945-1956. Liczba, położenie i działalność polityczna, Szczecin 1994.

${ }^{48}$ Mirosław Golon, Ludność żydowska w Polsce północnej po II wojnie światowej, [in:] Studia i szkice z dziejów Żydów w regionie Bałtyku, ed. Zenon H. NowAK, Toruń 1998, pp. 207-238. 
Jews, the latter of the researchers stated: "Although some of them managed to survive, as a result of persecutions and war they were thrown to distant places and settled in other countries. Only a small group of local Jews made an attempt to return to their former dwellings. In the new circumstances, this return proved for many to be only temporary - a very short episode on the way to Palestine, the USA or other countries"49. Janusz Mieczkowski pointed out that the rescued German Jews in Western Pomerania were a very closed community to Polish Jews and that in mid-1946 they left together with transports of displaced German people to Germany ${ }^{50}$.

The situation in Lower Silesia was very similar. At the end of 1945, this region was one of the largest Jewish population centres in Poland, inhabited by more than 10,000 Jews, but these were mostly concentration camp survivors from the territories of interwar Poland or Western European countries. Of all the German Jews living in this region before the Second World War, only 135 survived, including 30 residents of Wrocław. Leszek Ziątkowski says that these Jews quickly left Wrocław, one of the reasons for that being the conflict with their fellow believers from Poland ${ }^{51}$. However, A. Cohn did not leave Wrocław.

One can only guess what influenced his decision ${ }^{52}$. In part, it was certainly a matter of loyalty. In 1920. A. Cohn opted for Germany and showed loyalty to a state, which several years later issued a death sentence on him, his family and all the Jews. He did not choose this option for the second time. It seems that this was largely influenced by psychological factors. The Bydgoszcz period in the life of the Cohns was a very happy time which was partly spent with the company of Poles and interrupted by the decision of 1920 . When the dramatic situation repeated in Alfred's life in 1945, he decided to do something different - he decided to stay at home. And let us remember that what happened again was not only the change of nationality of the city and the region where he lived, but also a number of accompanying processes, including the migration of Polish and Jewish people from eastern territories. In the period 1945-1946, Wrocław became a place of intense Jewish settlement ${ }^{53}$.

The Cohn couple did not decide to leave Poland together with the German population in 1945 or as part of numerous migrations of the Jews from Poland to Palestine or other places, which took place later. Such attitude, compared to the decisions of other German Jews from Lower Silesia, was rare. The decisive factor could have been the fact that A. Cohn's identity, unlike that of other Jews

${ }^{49}$ Ibid., p. 208.

${ }^{50}$ J. MiecZKowsKi, op.cit., pp. 16-17.

${ }^{51}$ L. ZiąTKowsKi, op.cit., p. 113.

${ }^{52}$ It was impossible to find information about this period of A. Cohn's life. Also the search in the archives of the Institute of National Remembrance did not bring positive results.

${ }^{53}$ L. ZiąTKowski, op.cit., pp. 113-115; J. AdELson, op.cit., pp. 389 ff. 
from Wrocław, was formed on Polish territories that were part of the Prussian partition during the 20 years of his life, also spent among Poles.

The example of A. Cohn shows how complicated the problem of identity and sense of loyalty of the Jews from the former Prussian partition was. The literature on the subject is dominated by very simplistic and often emotional judgements on this subject, which result from the lack of in-depth source research. In 1998 Zenon Hubert Nowak wrote: "A thorough study of the issue of Jewish assimilation in West Prussia is a task yet to be undertaken by researchers" ${ }^{\prime 2}$. This statement remains valid after over 20 years, also in relation to the region of Poznan. The problem of Jewish assimilation in the German Reich has been studied to a much greater extent. But here, too, the authors do not decide to clearly define the identity of the Jewish population. Yfaat Weiss distinguishes between Jewish identity and civic loyalty of Jews to the German state and the issue of ethnicity ${ }^{55}$. According to Shulamit Volkov, 'Jewishness' should be treated not as a religion, not as an ethnic group or a modern nation, but as "a unique cultural system" 56 . Amos Elon writes about a dual or dichotomous identity of German Jews - "a German and a Jew - two souls in one body" ${ }^{57}$. None of the terms, neither assimilation nor acculturation, "reflects the dilemmas that shaped the unique identity of these people". Throughout the $19^{\text {th }}$ century and the first decades of the $20^{\text {th }}$ century, German Jews "struggled with their identity. [...] The true homeland of the German Jews was not [...] 'Germany' as such, but German language and culture" 58 .

Sociological research carried out by Irena Hurwic-Nowakowska in 1947-1950 also brought very interesting results. It was based on an anonymous survey held in major Jewish population centres in Poland and its results showed a number of specific features of the Jewish national consciousness, including the lack of correlation between the sense of nationality and pointing to a particular homeland, as well as the linguistic phenomenon that people who do not speak Yiddish, and often do not know it at all, describe their nationality as Jewish ${ }^{59}$.

And yet, the national identity of the Jews from the Prussian partition was characterized by additional specific features resulting from their functioning

${ }^{54}$ Z. H. Nowak, Dzieje Żydów, p. 31.

${ }^{55}$ Yfaat WeIss, Deutsche und polnische Juden vor dem Holocaust. Jüdische Identität zwischen Staatsbürgerschaft und Ethnizität 1933-1940, München 2000, pp. $219 \mathrm{ff}$.

${ }^{56}$ S. Volkov, op.cit., p. 134.

${ }^{57}$ Amos Elon, Bez wzajemności. Żydzi - Niemcy 1743-1933, trans. Krystyna BratKowsKa, Aleksandra GeLLER, Warszawa 2012, p. 13.

${ }^{58}$ Ibid., pp. 13-17.

${ }^{59}$ Irena Hurwic-Nowakowska, Żydzi polscy (1947-1950). Analiza więzi społecznej ludności żydowskiej, Warszawa 1996, pp. 52-55. 
'between' Poles and Germans. As early as in the first half of the $19^{\text {th }}$ century, one could see differences compared to the area of Old Prussia. In the Province of Posen and West Prussia, the Jews preserved their national identity for a longer period of time, despite a relatively fast process of acculturation in the field of language and education ${ }^{60}$.

In the book titled Narrative der Emanzipation. Autobiographische Identitätsentwürfe deutschsprachiger Juden aus der Emanzipationszeit, published a few years ago, Constantin Sonkwé Tayim departed from defining the identity of German Jews and attempted to describe it through examples from autobiographies $^{61}$. A similar assumption lays at the heart of this article. A. Cohn's biography shows that the issue of Jewish identity and a sense of Jewish loyalty in the case of the Prussian partition teemed with contradictions and is much more complex than the previous literature on the subject suggests, and thus fully deserves further research.

Translated by Tomasz Leszczuk

Received 31 March 2019

Received in revised form 4 October 2019

Accepted 24 October 2019

Dr hab. Elżbieta Alabrudzińska, prof. UMK

Faculty of Political Science and Security Studies

Nicolaus Copernicus University in Torun

e-mail:ea@umk.pl

ORCID ID: 0000-0002-2084-6439

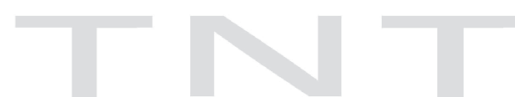

The Problem of Identity and the Sense of Loyalty of Jews

Coming from the Prussian Partition

on the EXAmple of Alfred Cohn (1901-1961)

Abstract

Key words: West Prussia, Greater Poland, German Jews, emancipation, acculturation, assimilation, national identity, loyalty to the state, Polish-Jewish relations

So far a very simplified picture of the transformation of the identity of Jews of West Prussia and Poznan land have functioned in the literature on the subject. The im-

${ }^{60}$ S. Kemlein, op.cit., pp. $255 \mathrm{ff}$.

${ }^{61}$ Constantin S. TAYım, Narrative der Emanzipation. Autobiographische Identitätsentwürfe deutschsprachiger Juden aus der Emanzipationszeit, Berlin-Boston 2013, pp. 74 ff. 
pulse to conduct the research on this issue became the publishing of the memories of Alfred Cohn, a typical German Jew, whose life and dramatic decisions show the complexity of the problem of identity and the sense of loyalty of the Jewish population of the territory of the Prussian partition. Alfred Cohn was close to recognizing himself as a German of the Jewish denomination. In 1920, without a shade of doubt, he decided to maintain loyalty to the German state and leave his family town Bydgoszcz, while in 1945 he decided the opposite. In order to clarify these contradictions, an analysis of the emancipation, acculturation and assimilation processes of the Jewish community of the territories of the Prussian partition of the $19^{\text {th }}$ century and the first two decades of the $20^{\text {th }}$ century was conducted. Subsequently, the results of this analysis were compared with studies on the identity of German Jews living in the Second and Third Reich. At least until the 1880s, the Jews of Greater Poland, and West Prussia considered themselves representatives of a separate nation, despite the already advanced process of assimilating German culture, customs and language, and showing loyalty to the German state. The assimilation reached its greatest intensity at the turn of the $19^{\text {th }}$ and $20^{\text {th }}$ centuries, leading to a strong integration of Jews with German society and the German state. This aggravated Polish-Jewish antagonism, especially in Greater Poland. After some of the lands of the former Prussian partition came under Polish rule, most Jews remained loyal to the German state, treating it as their homeland, and emigrated in the years 1918-1921 along with the majority of the German population. However, despite such decisions, despite the use of German as their mother tongue, and despite demonstrating German patriotism and the intense desire to blend in with German society, it is necessary to show great caution in the case of attempts to recognize the Jews of the Prussian partition only as a religious minority, although more than once they have defined themselves this way. In the Reich, Jews did not manage to merge with the German environment, either. They created their own Jewish-German cultural system. Their identity can be described as very specific, heterogeneous and shaped by contradictions and dilemmas. In the territories of the Prussian partition, the process of shaping the identity of German Jews was even more complicated as this community had to function also within the Polish society.

\author{
Das Problem der Identität Und des Loyalitätgefühls \\ DER AUS DEM PREUSSISCHEN TEILUNGgGebiet STAMMENDEN JUdeN \\ AM Beispiel von Alfred CoHn (1901-1961)
}

\title{
Abstract
}

Schlüsselwörter: Westpreußen, Großpolen, deutsche Juden, Emanzipation, Akkulturation, Assimilation, nationale Identität, Loyalität gegenüber dem Staat, polnisch-jüdische Beziehungen

Bisher wurde in der Literatur zu diesem Thema ein sehr vereinfachtes Bild der Identitätsveränderung der Juden in Westpreußen und in der Provinz Posen gezeichnet. 
Den Anstoß zur Erforschung dieser Problematik gaben die veröffentlichten Erinnerungen von Alfred Cohn, einem typischen deutschen Juden, dessen Leben und dramatische Entscheidungen die ganze Komplexität des Problems der Identität und des Loyalitätsgefühles der jüdischen Bevölkerung des preußischen Teilungsgebietes schildern. A. Cohn war nahe daran, sich als Deutschen mosaischen Glaubens zu sehen; 1920 traf er ohne jegliche Zweifel die Entscheidung, loyal gegenüber dem deutschen Staat zu bleiben und seine Heimatstadt Bromberg (poln. Bydgoszcz) zu verlassen; 1945 entschied er sich für das Gegenteil. Um diese Widersprüche zu klären, wurde eine Analyse der Emanzipations-, Akkulturations- und Assimilationsprozesse der jüdischen Gemeinde des preußischen Teilungsgebiets im 19. Jh. und in den ersten zwei Jahrzehnten des 20. Jh. durchgeführt und die Ergebnisse dieser Analyse wurden mit den Forschungen zur Identität der im Zweiten und Dritten Reich lebenden deutschen Juden zusammengestellt. Die Juden aus der Provinz Posen und aus Westpreußen sahen sich mindestens bis in die 80er Jahre des 19. Jh. als Vertreter einer getrennten Nation, obwohl der Prozess der Aneignung der deutschen Sprache, der Kultur und der Bräuche fortgeschritten war und sie ihre Loyalität gegenüber dem deutschen Staat bekundeten. Ihre Assimilation erreichte ihren Höhepunkt um die Wende des 19. zum 20. Jh. und führte zu einer starken Integration der Juden in die deutsche Gesellschaft und den deutschen Staat. Dies verschärfte den polnisch-jüdischen Antagonismus, insbesondere in der Provinz Posen. Nachdem ein Teil der Gebiete der preußischen Provinz unter polnische Herrschaft geriet, blieben die meisten Juden dem deutschen Staat als ihrer Vaterland treu und wanderten in den Jahren 1918-1921 zusammen mit der deutschen Bevölkerung aus. Trotz derartiger Entscheidungen, trotz der Benutzung der deutschen Sprache als Muttersprache, trotz der Demonstration von deutschem Patriotismus und des oft so intensiven Strebens danach, mit der deutschen Gesellschaft zu verschmelzen, ist jedoch große Vorsicht geboten, die Juden des preußischen Teilungsgebiets nur als eine religiöse Minderheit anzusehen, obwohl sie sich immer häufiger als solche bezeichneten. Auch im Reich gelang es den Juden nicht, mit dem deutschen Umfeld zu verschmelzen, sie schufen aber eher ihr eigenes jüdisch-deutsches Kultursystem. Beschreiben lässt sich ihre Identität als sehr spezifisch, heterogen sowie von Widersprüchen und Dilemmata geprägt. Im preußischen Teilungsgebiet war der Prozess der Identitätsbildung deutscher Juden noch komplizierter, und zwar dadurch, dass diese Gemeinschaft auch im polnischen Umfeld funktionierte.

\section{BIBLIOGRAPHY}

Adelson, Józef. Najnowsze dzieje Żydów w Polsce w zarysie (do 1950 roku). Edited by Jerzy Tomaszewski. Warszawa: Wydawnictwo Naukowe PWN, 1993.

Alabrudzińska, Elżbieta. Mniejszości wyznaniowe w Bydgoszczy w latach 1920-1939. Toruń: Wydawnictwo Uniwersytetu Mikołaja Kopernika, 1995.

Alabrudzińska, Elżbieta. “Stosunki religijne w Toruniu (1815-1914)." In Historia Torunia, vol. 3/1: W czasach zaboru pruskiego (1793-1920), edited by Marian Biskup, 390-419. Toruń: Wydawnictwo Towarzystwa Naukowego w Toruniu, 2003. 
Aschkewitz, Max. Zur Geschichte der Juden in Westpreussen. Marburg/Lahn: Johann Gottfried Herder-Institut, 1967.

Biegański, Zdzisław. Mniejszość żydowska w Bydgoszczy 1920-1939. Bydgoszcz: Wydawnictwo Uczelniane WSP w Bydgoszczy, 1999.

Broniewicz, Lucjan. “Tworzenie się inteligencji żydowskiej w Prusach Zachodnich. Żydowscy absolwenci gimnazjów przed 1914 rokiem.” In Emancypacja - asymilacja - antysemityzm. Żydzi na Pomorzu w XIX i XX wieku, edited by Zenon H. Nowak, 27-42. Toruń: Wydawnictwo Adam Marszałek, 1992.

Cohn, Alfred. Erinnerungen an Bromberg. Wspomnienia o Bydgoszczy. Edited by Elżbieta Alabrudzińska and Barbara Janiszewska-Mincer. Toruń: Wydawnictwo Adam Marszałek, 2001.

Cohn, Willy. Verwehte Spuren. Erinnerungen an das Breslauer Judentum vor seinem Untergang. Edited by Norbert Conrads. Köln, Weimar, Wien: Böhlau Verlag, 1995.

Cohn, Willy. Żadnego prawa - nigdzie. Dziennik z Breslau 1933-1941. Wybrane fragmenty. Edited by Norbert Conrads, translated by Viktor Grotowicz. Wrocław: Wydawnictwo Via Nova, 2010.

Cygański, Mirosław. “Żydzi poznańscy, pomorscy oraz śląscy wobec Polaków i Niemców pruskich w latach 1816-1939.” Studia Śląskie 55 (1997): 57-94.

Eisenbach, Artur. Emancypacja Żydów na ziemiach polskich 1785-1870 na tle europejskim. Warszawa: Państwowy Instytut Wydawniczy, 1988.

Elon, Amos. Bez wzajemności. Żydzi - Niemcy 1743-1933. Translated by Krystyna Bratkowska and Aleksandra Geller. Warszawa: Wydawnictwo Nisza, 2012.

Fehrs, Jörg H. “' ‘..., daß sie sich mit Stolz Juden nennen.' Die Erziehung jüdischer Kinder in Ost- und Westpreußen im 19. Jahrhundert." In Zur Geschichte und Kultur der Juden in Ost- und Westpreußen, edited by Michael Brocke, Margret Heitmann and Harald Lordick, 239-280. Hildesheim, Zürich, New York: Georg Olms Verlag, 2000.

Golon, Mirosław. “Ludność żydowska w Polsce północnej po II wojnie światowej.” In Studia i szkice z dziejów Żydów w regionie Battyku, edited by Zenon H. Nowak, 207-238. Toruń: Wydawnictwo Uniwersytetu Mikołaja Kopernika, 1998.

Grabski, August, Maciej Pisarski and Albert Stankowski. Studia z dziejów i kultury Żydów w Polsce po 1945 roku. Warszawa: Wydawnictwo TRIO, 1997.

Guesnet, François. Polnische Juden im 19. Jahrhundert. Lebensbedingungen, Rechtsnormen und Organisation im Wandel. Köln, Weimar, Wien: Böhlau, 1998.

Hurwic-Nowakowska, Irena. Żydzi polscy (1947-1950). Analiza więzi społecznej ludności żydowskiej. Warszawa: Wydawnictwo Instytutu Filozofii i Socjologii Polskiej Akademii Nauk, 1996.

Jersch-Wenzel, Stefi. "Zur Geschichte der jüdischen Bevölkerung in der Provinz Posen im 19. Jahrhundert." In Juden in Ostmitteleuropa. Von der Emanzipation bis zum Ersten Weltkrieg, edited by Gotthold Rhode, 73-84. Marburg/Lahn: J. G. HerderInstitut, 1989.

Kemlein, Sophia. Die Posener Juden 1815-1848. Entwicklungsprozesse einer polnischen Judenheit unter preußischer Herrschaft. Hamburg: Dölling und Galitz Verlag, 1997.

Kiec, Olgierd. Protestantyzm w Poznańskiem 1815-1918. Warszawa: Wydawnictwo Naukowe „Semper”, 2001. 
Kutta, Janusz. “Społeczeństwo Bydgoszczy w latach 1920-1939.” In Historia Bydgoszczy, vol. 2/1, edited by Marian Biskup, 177-232. Bydgoszcz: Bydgoskie Towarzystwo Naukowe, 1999.

Łaszkiewicz, Tomasz. Żydzi w Inowrocławiu w okresie międzywojennym (1919-1939). Inowrocław: Oficyna Wydawnicza Muzeum im. Jana Kasprowicza, 1997.

Matelski, Dariusz. Niemcy w Polsce w XX wieku. Warszawa, Poznań: Wydawnictwo Naukowe PWN, 1999.

Mieczkowski, Janusz. Żydzi, Niemcy i Ukraińcy na Pomorzu Zachodnim w latach 1945-1956. Liczba, położenie i działalność polityczna. Szczecin: Wydawnictwo Naukowe Uniwersytetu Szczecińskiego, 1994.

Mincer, Franciszek. Dzieje Bydgoszczy do roku 1806. Zielona Góra: Wydawnictwo Wyższej Szkoły Pedagogicznej im. Tadeusza Kotarbińskiego, 1992.

Niedzielska, Magdalena. “Życie polityczne i kulturalne Torunia (1815-1914).” In Historia Torunia, vol. 3/1: W czasach zaboru pruskiego (1793-1920), edited by Marian Biskup, 220-389. Toruń: Wydawnictwo Towarzystwa Naukowego w Toruniu, 2003.

Nowak, Zenon H. “Dzieje gminy żydowskiej w Toruniu (1815-1939). Zarys.” In Mniejszości narodowe i wyznaniowe w Toruniu w XIX $i$ XX w., edited by Mieczysław Wojciechowski, 27-38. Toruń: Wydawnictwo Uniwersytetu Mikołaja Kopernika, 1993.

Nowak, Zenon H. “Dzieje Żydów na Pomorzu. Stan badań i postulaty badawcze.” In Mniejszości narodowe i wyznaniowe na Pomorzu w XIX i XX wieku, edited by Mieczysław Wojciechowski, 23-38. Toruń: Wydawnictwo Uniwersytetu Mikołaja Kopernika, 1998.

Nowak, Zenon H. “Gmina Wyznaniowa Żydowska w Toruniu w latach 1920-1939.” In Gminy Wyznaniowe Żydowskie w województwie pomorskim w okresie międzywojennym (1920-1939), edited by Jan Sziling, 59-74. Toruń: Wydawnictwo Uniwersytetu Mikołaja Kopernika, 1995.

Nowak, Zenon H. "Sprawa emancypacji Żydów w Prusach Zachodnich w pierwszej połowie XIX wieku.” In Emancypacja - asymilacja - antysemityzm. Żydzi na Pomorzu w XIX i XX wieku, edited by Zenon H. Nowak, 7-16. Toruń: Wydawnictwo Adam Marszałek, 1992.

Rautenberg, Hans-Werner. "Zur Geschichte des Judentums in Pommern und Westpreußen zwischen Emanzipation und Erstem Weltkrieg." In Juden in Ostmitteleuropa. Von der Emanzipation bis zum Ersten Weltkrieg, edited by Gotthold Rhode, 49-72. Marburg/Lahn: J. G. Herder-Institut, 1989.

Schiper, Ignacy. “Żydzi pod zaborem pruskim.” In Żydzi w Polsce Odrodzonej. Działalność społeczna, gospodarcza, oświatowa i kulturalna, vol. 1, edited by Ignacy Schiper, Aryeh Tartakower and Aleksander Hafftka, 551-562. Warszawa: Wydawnictwo „Żydzi w Polsce Odrodzonej”, 1932.

Schumann, Peter. "Über jüdische Deutsche und die Assimilation." In Emancypacja asymilacja - antysemityzm. Żydzi na Pomorzu w XIX i XX wieku, edited by Zenon H. Nowak, 165-172. Toruń: Wydawnictwo Adam Marszałek, 1992.

Sziling, Jan. "Gminy wyznaniowe żydowskie w województwie pomorskim w latach 1920-1939 (Liczebność i rozmieszczenie).” In Mniejszości narodowe i wyznanio- 
we w województwie pomorskim w okresie międzywojennym (1920-1939), edited by Mieczysław Wojciechowski, 45-60. Toruń: Wydawnictwo Adam Marszałek, 1991.

Tayim, Constantin S. Narrative der Emanzipation. Autobiographische Identitätsentwürfe deutschsprachiger Juden aus der Emanzipationszeit. Berlin, Boston: De Gruyter, 2013.

Tomaszewski, Jerzy. Zarys dziejów Żydów w Polsce w latach 1918-1939. Warszawa: Wydawnictwa Uniwersytetu Warszawskiego, 1990.

Toury, Jacob. Soziale und politische Geschichte der Juden in Deutschland 1847-1871. Zwischen Revolution, Reaktion und Emanzipation. Düsseldorf: Droste, 1977.

Volkov, Shulamit. Pomyst na nowoczesność. Żydzi niemieccy w XIX i na początku XX wieku. Translated by Justyna Górny and Patrycja Pieńkowska. Warszawa: PW „Wiedza Powszechna”, Niemiecki Instytut Historyczny, 2006.

Wajda, Kazimierz. "Awans i asymilacja. Na przykładzie społeczności żydowskiej Chełmży w XIX i na początku XX wieku.” In Emancypacja - asymilacja - antysemityzm. Żydzi na Pomorzu w XIX i XX wieku, edited by Zenon H. Nowak, 17-26. Toruń: Wydawnictwo Adam Marszałek, 1992.

Wajda, Kazimierz. "Ludność, jej rozwój i struktura." In Historia Bydgoszczy, vol. 1: Do roku 1920, edited by Marian Biskup, 468-471. Warszawa, Poznań: Państwowe Wydawnictwo Naukowe, 1991.

Wajda, Kazimierz. "Przemiany terytorialne i ludnościowe w latach 1850-1914." In Historia Bydgoszczy, vol. 1: Do roku 1920, edited by Marian Biskup, 505-529. Warszawa, Poznań: Państwowe Wydawnictwo Naukowe, 1991.

Wasiutyński, Bohdan. Ludność żydowska w Polsce w wiekach XIX i XX. Studium statystyczne. Warszawa: Wydawnictwo Kasy im. Mianowskiego, Instytutu Popierania Nauki, 1930.

Waszkiewicz, Zofia. “Żydzi w Grudziądzu (1920-1939).” In Emancypacja - asymilacja - antysemityzm. Żydzi na Pomorzu w XIX i XX wieku, edited by Zenon H. Nowak, 91-108. Toruń: Wydawnictwo Adam Marszałek, 1992.

Weeks, Theodore R. "Jews on the Polish Lands and Polish-Jewish Relations 1795-1914." In Historie Polski w XIX wieku, vol. 4: Narody, wyznania, emigracje, porównania, edited by Andrzej Nowak, 63-114. Warszawa: Wydawnictwo DIG, 2015.

Weiss, Yfaat. Deutsche und polnische Juden vor dem Holocaust. Jüdische Identität zwischen Staatsbürgerschaft und Ethnizität 1933-1940. München: R. Oldenbourg Verlag, 2000.

Wippermann, Wolfgang. "Probleme und Aufgaben der Beziehungsgeschichte zwischen Deutschen, Polen und Juden." In Deutsche - Polen - Juden. Ihre Beziehungen von den Anfängen bis ins 20. Jahrhundert, edited by Stefi Jersch-Wenzel, 1-48. Berlin: Colloquium Verlag, 1987.

Wojciechowski, Mieczysław. "Mniejszości narodowe w Toruniu w okresie międzywojennym (1920-1939).” In Historia Torunia, vol. 3/2: W czasach Polski Odrodzonej i okupacji niemieckiej (1920-1945), edited by Marian Biskup, 195-234. Toruń: Wydawnictwo Towarzystwa Naukowego w Toruniu, 2006.

Wojciechowski, Mieczysław. "Niemcy, Polacy i Żydzi w Prusach Zachodnich w latach 1877-1920." In Ze soba, obok siebie, przeciwko sobie. Polacy, Żydzi, Austriacy i Niemcy w XIX i na początku XX wieku, 167-188. Kraków: Znak, 1995. 
Wojciechowski, Mieczysław. "W okresie pierwszej wojny światowej i powstania wielkopolskiego (1914-1920).” In Historia Bydgoszczy, vol. 1: Do roku 1920, edited by Marian Biskup, 600-636. Warszawa, Poznań: Państwowe Wydawnictwo Naukowe, 1991.

Wróbel, Piotr. “Żydzi wielkopolscy przed I wojną światową.” Biuletyn Żydowskiego Instytutu Historycznego w Polsce (1991) issue 1: 31-55.

Wróbel, Piotr. Zarys dziejów Żydów na ziemiach polskich w latach 1880-1918. Warszawa: Wydawnictwa Uniwersytetu Warszawskiego, 1991.

Ziątkowski, Leszek. Dzieje Żydów we Wrocławiu. Wrocław: Wydawnictwo Dolnośląskie, 2000.

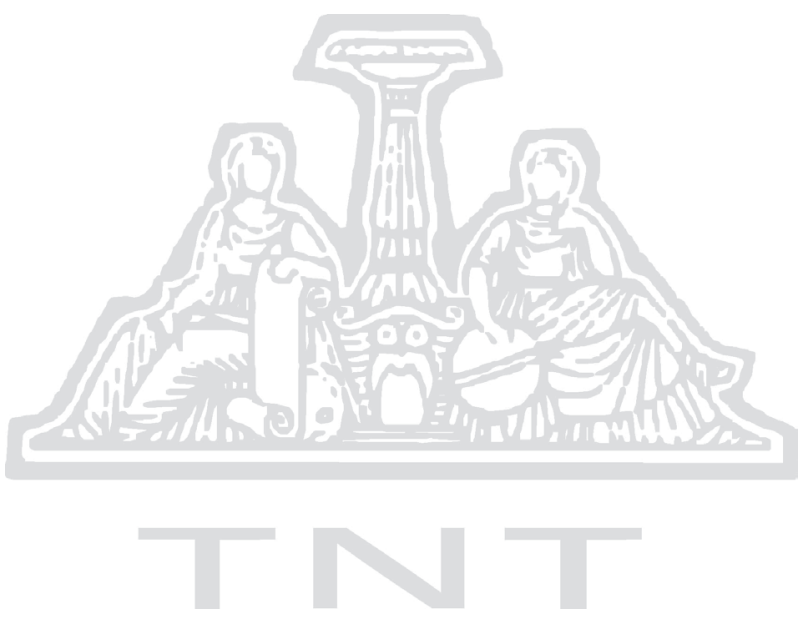

